\title{
Altered Ion Channels in an Animal Model of Charcot-Marie- Tooth Disease Type IA
}

\author{
Jérôme J. Devaux and Steven S. Scherer \\ Department of Neurology, University of Pennsylvania Medical Center, Philadelphia, Pennsylvania 19104
}

How demyelination and remyelination affect the function of myelinated axons is a fundamental aspect of demyelinating diseases. We examined this issue in Trembler-J mice, a genetically authentic model of a dominantly inherited demyelinating neuropathy of humans. The $\mathrm{K}^{+}$channels Kv1.1 and Kv1.2 channels were often improperly located in the paranodal axon membrane, typically associated with improperly formed paranodes, and in unmyelinated segments between internodes. As in wild-type nerves, Trembler-J nodes contained Nav1.6, ankyrin-G, $\beta$ IV-spectrin, and KCNQ2, but, unlike wild-type nerves, they also contained Kv3.1b and Nav1.8. In unmyelinated segments bordered by myelin sheaths, these proteins were clustered in heminodes and did not appear to be diffusely localized in the unmyelinated segments themselves. Nodes and heminodes were contacted by Schwann cells processes that did not have the ultrastructural or molecular characteristics of mature microvilli. Despite the presence of Nav1.8, a tetrodotoxin-resistant sodium channel, sciatic nerve conduction was at least as sensitive to tetrodotoxin in Trembler-J nerves as in wild-type nerves. Thus, the profound reorganization of axonal ion channels and the aberrant expression of novel ion channels likely contribute to the altered conduction in Trembler-Jnerves.

Key words: myelin; CMT; PMP22; node of Ranvier; potassium channels; axonal conduction

\section{Introduction}

The structure of the myelin sheath contributes to the unique spatial segregation of axonal ion channels (Scherer et al., 2004). Voltage-gated $\mathrm{Na}^{+}$(Nav) channels are concentrated at nodes of Ranvier, anchored to the actin cytoskeleton by nodal isoforms of ankyrin-G and $\beta \mathrm{IV}$-spectrin. Juxtaparanodal voltage-dependant $\mathrm{K}^{+}$channels, Kv1.1 and Kv1.2, are separated from the nodal region by paranodal septate-like junctions, which are formed by the association of neurofascin- $155 \mathrm{kDa}$ on the glial side with heterodimers of contactin and Caspr on the axonal side (Poliak and Peles, 2003). The fast activation and inactivation of nodal Nav channels and the important nodal leakage current are sufficient to regenerate and repolarize the action potential (AP) (Schwarz and Eikhof, 1987; Schwarz et al., 1995). Nodal voltagedependant KCNQ2, as well as juxtaparanodal Kv1.1 and Kv1.2 $\mathrm{K}^{+}$channels, prevent aberrant firing after the AP. Voltagedependant $\mathrm{K}^{+}$channels are not involved in AP repolarization at PNS nodes in mammals, and juxtaparanodal Kv1.1 and Kv1.2 may only serve to dampen the appearance of aberrant firing after the AP. Indeed, patients with mutation in the KCNA1 gene, which encodes Kv1.1, present myokymic syndromes (Browne et al., 1994; Eunson et al., 2000). However, in the CNS, Kv3.1b is

Received Aug. 13, 2004; revised Nov. 22, 2004; accepted Dec. 16, 2004.

This work was supported by a Charcot-Marie-Tooth Association fellowship (J.J.D.), a National Multiple Sclerosis Society fellowship (J.J.D.), and National Institutes of Health Grant R01 NS42878 (S.S.S.). We thank Drs. Vann Bennett, Ed Cooper, Laurence Goutebroze, John Wood, Rock Levinson, Ori Peles, Matt Rasband, and Philippe Soriano for their generous gifts of antibodies, and Erich Sirkowski for assistance with electron microscopy.

Correspondence should be addressed to Dr. Jérôme J. Devaux, University of Pennsylvania Medical Center, Room 464, Stemmler Hall, 36th Street and Hamilton Walk, Philadelphia, PA 19104-6077.E-mail: jdevaux@mail.med.upenn.edu. DOI:10.1523/JNEUROSCI.3328-04.2005

Copyright $\odot 2005$ Society for Neuroscience $\quad$ 0270-6474/05/251470-11\$15.00/0 present at nodes and may participate to the repolarization (Devaux et al., 2002, 2003).

In addition to its biophysical consequences on the conduction of APs, demyelination alters the distribution of the axonal ion channels, which may worsen the regeneration and/or propagation of APs (Poliak and Peles, 2003; Scherer et al., 2004). It remains to be determined whether this occurs in inherited demyelinating neuropathies, such as Charcot-Marie-Tooth disease type 1 (CMT1). These are common diseases caused by mutations in genes expressed by myelinating Schwann cells (Dyck, 1993; Lupski and Garcia, 2001; Wrabetz et al., 2001). The most frequent forms, CMT1A, CMT1B, and CMT1X, are caused by mutations in $P M P 22, M P Z$, and GJB1, which encode three components of the myelin sheath, peripheral myelin protein $22 \mathrm{kDa}$ (PMP22), myelin protein zero, and connexin 32 , respectively. Although there are many causes of demyelination (Suter and Scherer, 2003), the fundamental changes in the demyelinated axon may be the same and represent an opportunity to treat these, as well as other, kinds of demyelinating diseases.

We examined the composition and distribution of voltagegated ion channels and their possible physiological consequences in an animal model of CMT1A, the Trembler-J mouse. These mice have a dominantly inherited demyelinating neuropathy caused by a point mutation in Pmp22 that results in a Leu16Pro amino acid substitution, also found in one family with CMT1A (Suter et al., 1992a; Valentijn et al., 1992). Heterozygote Trembler-J $\left(\right.$ Pmp $\left.22^{\mathrm{Tr} / /+}\right)$ mice have a moderately severe demyelinating neuropathy with segmental demyelination and remyelination, as well as axonal atrophy (Henry et al., 1983; Robertson et al., 1997). We report several changes heretofore not described: altered paranodal junctions, abnormally distributed Kv1.1 and Kv1.2 subunits, and heminodes and nodes that contain two un- 
usual subunits, Nav1.8 and Kv3.1b. As described previously for heterozygous Trembler (Pmp22 $2^{\mathrm{Tr} /+}$ ) mice (Low and McLeod, 1977), which are allelic to Trembler-J, these pathological changes are associated with slowed conduction $(9 \mathrm{~m} / \mathrm{s})$, decreased amplitude, and dispersion of the compound AP (CAP), as well as an increased refractory period.

\section{Materials and Methods}

Electron microscopy. Mice were deeply anesthetized with chloral hydrate and then perfused with $0.9 \% \mathrm{NaCl}$, followed by $3 \%$ glutaraldehyde in $0.1 \mathrm{M}$ phosphate buffer $(\mathrm{PB})$. The sciatic and femoral nerves were removed and placed in fresh fixative overnight at $4^{\circ} \mathrm{C}$, rinsed in $\mathrm{PB}$, postfixed in 1\% OsO4 (in $\mathrm{PB}$ ), dehydrated in an ascending series of ethanol, and embedded in epoxy. Semithin sections were stained with toluidine blue; thin sections were stained with lead citrate and uranyl acetate and were viewed with a Zeiss (Oberkochen, Germany) EM 902 electron microscope.

Immunohistochemistry. Three-month-old male and female Pmp22 $2^{\mathrm{TrJ} /+}$ mice and their Pmp $22^{+/+}$littermates were used unless otherwise indicated. The mice were killed according to University of Pennsylvania Institutional Animal Care and Use Committee guidelines. Teased nerve fibers were prepared from unfixed sciatic nerves as well as lumbar dorsal or ventral roots, dried on glass slides overnight at room temperature, and stored at $-20^{\circ} \mathrm{C}$. Unfixed lumbar dorsal root ganglia (DRGs) and spinal cords were embedded in OCT, and 5- to 10- $\mu \mathrm{m}$-thick sections were thaw mounted onto glass slides. Frozen sections and teased fibers were permeabilized by immersion in $-20^{\circ} \mathrm{C}$ acetone for $10 \mathrm{~min}$, blocked at room temperature for $1 \mathrm{~h}$ with $5 \%$ fish skin gelatin containing $0.1 \%$ Triton X-100 in PBS, and incubated overnight at $4^{\circ} \mathrm{C}$ with various combinations of primary antibodies: rabbit antisera against KCNQ2 [1:200 (Cooper et al., 2001)], Kv3.1b (1:100; Alomone Labs, Jerusalem, Israel), Kv1.2 (1:100; Alomone Labs), Nav1.6 [1:100 (Caldwell et al., 2000)], Nav1.8 [1:100 (Caldwell et al., 2000)], Nav1.8 [1:500 (Djouhri et al., 2003)], ankyrin-G [1:100 (Jenkins and Bennett, 2001; Jenkins et al., 2001)], contactin [1:100 (Rios et al., 2000)], ezrin-binding protein $50 \mathrm{kDa}$ (EBP-50) (ab3452; 1:100; Abcam, Cambridge, MA), syndecan-3 [1:300 (Goutebroze et al., 2003)], or Caspr [1:500 (Peles et al., 1997)]; and mouse monoclonal antibodies against panNav channels (K58/35; 1:250; Sigma, St. Louis, MO), Nav1.2 [1:100 (Rasband et al., 1999; Boiko et al., 2001)], Nav1.2 (1:50; Upstate Biotechnology, Lake Placid, NY), Caspr [1:50 (Rasband and Trimmer, 2001)], annexin II light chain (1:50; BD Transduction Laboratories, San Jose, CA), or myelin-associated glycoprotein (MAG) (clone 513, 1:100; Boehringer Mannheim, Indianapolis, IN); rat monoclonal antibody against E-cadherin (1:50; Sigma); chicken antibody against $\beta I V$-spectrin [1:500 (Komada and Soriano, 2002)]; and a soluble construct of receptor protein tyrosine phosphatase $\beta$ conjugated to the human Fc fragment $(\mathrm{RPTP} \beta-\mathrm{Fc})$ [1:3 (Peles et al., 1995)]. The slides were then washed several times and incubated with the appropriate fluorescein- and rhodamineconjugated donkey cross-affinity-purified secondary antibodies (1:100; Jackson ImmunoResearch, West Grove, PA). Slides were stained with 4', $6^{\prime}$ diamidino-2-phenylindole (DAPI) to visualize cell nuclei, mounted with Vectashield (Vector Laboratories, Burlingame, CA), examined by epifluorescence with tetramethylrhodamine isothiocyanate (TRITC) and fluorescein isothiocyanate (FITC) optics on a Leica (Nussloch, Germany) DMR light microscope, and photographed with a cooled Hamamatsu (Shizouka, Japan) camera. Digital images were manipulated into figures with Adobe Photoshop (Adobe Systems, San Jose, CA).

For the quantitative study of paranodes, the diameter and length of individual Caspr-positive paranodes was measured in teased fibers from Pmp $22^{\mathrm{Tr} / /+}$ mice and their Pmp $22^{+/+}$littermates after immunolabeling with a rabbit antiserum against Caspr. For the quantification of Kv3.1b, nodes were identified using a mouse antibody against panNav. For Nav1.8, paranodes were labeled using a rat antibody against E-cadherin. For Kv1.2 quantification, nodes or paranodes were identified using a mouse antibody against panNav or MAG, and data were pooled together because of their similarity.

Immunoblots. Membranes were prepared from fresh spinal cord, and sciatic nerves were dissected from adult $P m p-22^{\mathrm{TrJ} /+}$ mice and their Pmp- $22^{+1+}$ littermates. Tissues were homogenized in ice-cold $0.32 \mathrm{M}$ sucrose and $5 \mathrm{~mm}$ Tris-Cl, $\mathrm{pH} 7.4$, containing protease inhibitors [2 mM EDTA, $1 \mu \mathrm{g} / \mathrm{ml}$ leupeptin and aprotinin, and $0.5 \mathrm{~mm}$ phenylmethylsulfonyl fluoride (Sigma)], and the homogenates were centrifuged for 10 $\min$ at $750 \times g$. The supernatants were sedimented for $60 \mathrm{~min}$ at $17,000 \times g$, and the resulting pellets were resuspended in $1 \mathrm{~mm}$ EDTA and $5 \mathrm{~mm}$ TRIS, $\mathrm{pH} 8.2$, plus protease inhibitors, homogenized, and placed on ice for $30 \mathrm{~min}$. The lysate membranes were then centrifuged 40 min at 27,000 $\times g$, and the pellet (P3) was resuspended in $150 \mathrm{~mm} \mathrm{NaCl}$ and $25 \mathrm{~mm}$ Tris, $\mathrm{pH} 7.4$, plus protease inhibitors, and stored at $-80^{\circ} \mathrm{C}$. Protein concentration was determined using the Bio-Rad (Hercules, CA) kit. From each sample, $100 \mu \mathrm{g}$ of protein were loaded on a 7.5 or $5 \%$ SDS-PAGE gel and then transferred onto a polyvinylidene difluoride membrane. Membranes were blocked for $1 \mathrm{~h}$ with $5 \%$ powdered skim milk- $0.5 \%$ Tween 20 in PBS and incubated with rabbit affinity-purified antiserum against Nav1.8 (1:5000), Kv3.1b (1:500), or Kv1.1 (1:500). After several washes, the blots were incubated in peroxidase-coupled secondary antibodies against rabbit (1:2000; Jackson ImmunoResearch) for $1 \mathrm{~h}$ at room temperature, washed several times, and revealed using ECL plus (Amersham Biosciences, Arlington Heights, IL).

Electrophysiology. After the mice were killed, the sciatic nerves were quickly dissected from Pmp22 2 TrJ/+ and their Pmp22 $2^{+/+}$littermates and transferred into artificial CSF (ACSF), which contained the following (in mm): $126 \mathrm{NaCl}, 3 \mathrm{KCl}, 2 \mathrm{CaCl}_{2}, 2 \mathrm{MgSO}_{4}, 1.25 \mathrm{NaH}_{2} \mathrm{PO}_{4}, 26 \mathrm{NaHCO}_{3}$, and 10 dextrose, $\mathrm{pH}$ 7.4-7.5. The nerves were cut into $1 \mathrm{~cm}$ segments, desheathed to maximize the access to drugs, placed in a fourcompartment recording chamber, and perfused (at $1-2 \mathrm{ml} / \mathrm{min}$ ) in $32^{\circ} \mathrm{C}$ ACSF equilibrated with $95 \% \mathrm{O}_{2}-5 \% \mathrm{CO}_{2}$. The distal end was stimulated supramaximally (100 $\mu$ s duration) through two electrodes isolated with Vaseline, and recordings were performed at the proximal end. Signals were amplified, digitized at $500 \mathrm{~Hz}$, and stored on a hard disk. Drugs were applied in the two central compartments of the chamber, separated from each other by Vaseline; measurements were made once the effects had reached a steady state, typically $30-45 \mathrm{~min}$ after application. Nerves were continuously stimulated at a frequency of $0.25 \mathrm{~Hz}$. The delay and duration of CAPs were calculated at half the maximal amplitude; the maximal amplitude and area under the curve were also measured (Stys et al., 1991). For recruitment analysis, the amplitude of CAPs was measured and plotted as a function of the stimulation intensity. For refractory period analysis, two stimuli were applied at different intervals, and the amplitude of the second CAP was measured and plotted as a function of the stimulus interval.

\section{Results}

\section{Demyelinated and remyelinated axons in Trembler-J mice}

We examined the morphology of myelinated fibers by immunostaining teased fibers from adult sciatic nerves for E-cadherin or MAG. These molecules are localized to noncompact myelin (paranodes, incisures, and mesaxons) (Martini and Schachner, 1986; Fannon et al., 1995), and their robust immunostaining facilitated the visualization of the of the internodal length and the myelin sheath itself. As observed previously in Trembler mice (Beuche and Friede, 1985; Friede, 1986), their internodal length varied remarkably. Some myelin sheaths had relatively normal internodal lengths (hundreds of micrometers), with E-cadherin/ MAG staining that was appropriately pronounced at paranodes and incisures (Figs. 1, 2) (see Fig. 4). Most myelin sheaths, however, were inappropriately short (as little as $20 \mu \mathrm{m}$ ) (Figs. $1 \mathrm{~B}, 3 \mathrm{~A}$ ) and had more diffuse E-cadherin/MAG staining. Normalappearing myelin sheaths and abnormally short/thin myelin sheaths were found on the same axon (Figs. 1,2), supporting the idea that demyelination and remyelination are concurrent and ongoing processes in adult Trembler-J nerves (Sancho et al., 2001).

Unmyelinated axonal segments between myelin internodes were a common finding (Figs. 1-5). These varied from a few micrometers to tens of micrometers in length. Many of the longer ones had an associated Schwann cell (as evidenced by a DAPI- 
positive elliptical nucleus) (Fig. $4 B$ ) that presumably ensheathed the unmyelinated segment. Most unmyelinated segments, however, had no associated Schwann cell. Electron microscopy of adult Trembler-J nerves corroborates these findings: many large axons were ensheathed by Schwann cell processes, and some even lacked any ensheathment (Fig. 3) (Henry et al., 1983; Robertson et al., 1997).

\section{Altered paranodes but intact septate-like junctions}

To evaluate the organization of the paranodal region, we examined teased fibers that were immunostained for Caspr. Clustered Caspr staining was found in the paranodal region of every E-cadherin/MAG-positive myelin sheath, and diffuse Caspr staining was found in some unmyelinated segments (Fig. 1A,B). The length of paranodal Caspr staining, however, was significantly shorter in Trembler-J than in wild-type (WT) axons of equal diameter (Fig. 1C-E). Because the paranode is formed by the lateral edge of the myelin sheath, the shorter length of Caspr staining is in keeping with the idea that the myelin sheaths are thinner in Trembler-J mice. Electron microscopy confirmed that myelin sheaths are thinner (Fig. 3B) and that paranodes have septate-like junctions (Fig. $3 D$ ), demonstrating that paranodal adhesive junctions are not disrupted in the Trembler-J mice.

\section{Altered organization of the ion channels in Trembler-J nodes}

We first examined the localization of Nav channels in Trembler-J nerves using a monoclonal antibody that recognizes all isoforms (panNav). Nav channels were clustered at nodes; paranodes or internodes were not detectably stained (Figs. 2, 4, 5). In unmyelinated segments, Nav channels were clustered at heminodes flanking the myelin sheaths; no staining was seen in the unmyelinated segment itself (Figs. 2, 4, 5). We observed the same patterns of immunostaining for $\beta \mathrm{IV}$-spectrin (Fig. $2 B$ ) and ankyrin-G (data not shown), the two proteins that link Nav channels to the nodal actin cytoskeleton (Kordeli et al., 1995; Berghs et al., 2000), and for KCNQ2 (Fig. 4F, G,K).

In developing nodes, Nav1.6 replaces Nav1.2 (Boiko et al., 2001; Kaplan et al., 2001), but the expression of the latter is maintained or reinduced in certain pathological conditions (Craner et al., 2003; Rasband et al., 2003; Rios et al., 2003). To determine whether this occurs in Trembler-J mice, we double-labeled teased fibers for Nav1.2 and Nav1.6. Nav1.6, but not Nav1.2, was found at nodes and heminodes in both adult WT and Trembler-J mice (Fig. 2C). Nav1.6 was also absent from unmyelinated segments of axons, in agreement with the lack of panNav staining. The Nav1.2 antibody labeled initial segments of hippocampal neurons and some nodes in postnatal day 10 WT mouse sciatic nerve, confirming its proper reactivity (data not shown). These data dem- onstrate that nodes and heminodes in Trembler-J mice have the same molecular components as normal nodes.

\section{Schwann cell specializations at nodes and heminodes}

In our electron microscopic studies, we noticed that nodes and heminodes bordering unmyelinated segments were contacted by Schwann cells processes that were much larger and lacked the actin bundles that characterize Schwann cell microvilli in mature nodes (Fig. $3 B, C$ ). Because the microvilli of normal adult nodes contain the ERM proteins ezrin, radixin, moesin, as well as EBP-50 (Melendez-Vasquez et al., 2001; Scherer et al., 2001), we labeled Trembler-J fibers with EBP-50. There was punctate EBP-50 staining along myelin sheaths (Fig. 2D) and detectable accumulations of EBP-50 at $40 \%$ of nodes and heminodes in Trembler- $J$ mice $(n=305)$, in contrast to $98 \%$ of nodes in WT mice $(n=296)$ (Fig. $2 D$, inset). We tested the possibility that only mature nodes have EBP-50 by staining neonatal WT sciatic nerve for EBP-50 (P3, P10, and 3 months old). Even at P3, almost all 

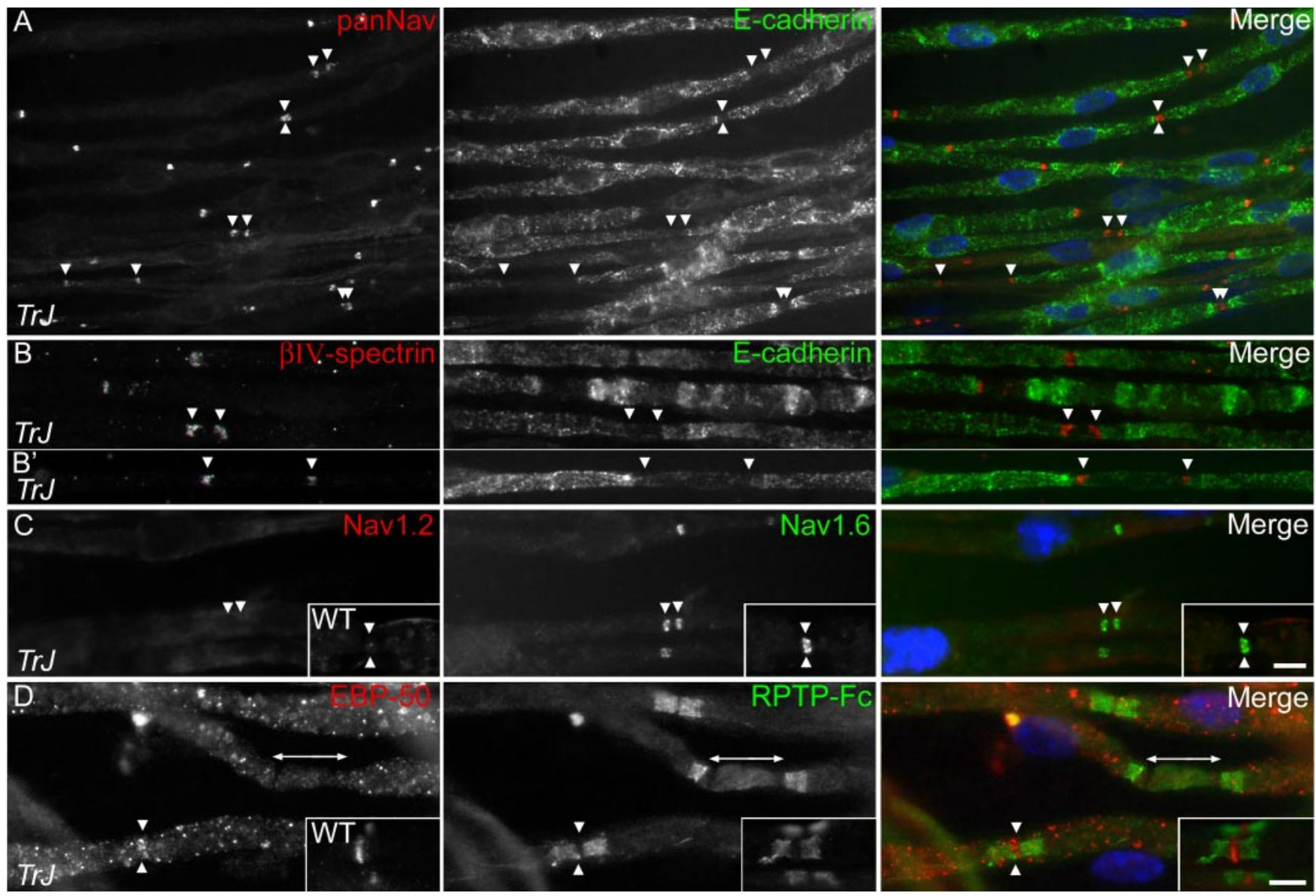

Figure 2. Organization of nodes and heminodes in Trembler-J mice. These are images of unfixed teased sciatic nerve fibers from Trembler-J $(T r J)(A-D)$ and WT (insets in $C, D)$ mice, labeled as indicated. Nodes and heminodes contain Nav channels ( $A$ ), $\beta \mathrm{IV}$-spectrin $(B)$, and Nav1.6 ( $($ ) but not Nav1.2 ( () . Unmyelinated segments (between heminodes) do not contain detectable levels of Nav channels or $\beta$ IV-spectrin. A minority of Trembler-J nodes contain detectable amounts of EBP-50, a marker of Schwann cell microvilli ( $D$ ). Paranodes are labeled using RPTP $\beta$-Fc, which binds to contactin. Scale bar, $10 \mu \mathrm{m}$.

nodes were EBP-50 positive (supplemental Fig. 1, available at www.jneurosci.org as supplemental material), indicating that the lack of nodal EBP-50 staining in Trembler-J nodes is not simply the result of their immaturity. Similarly, another marker of nodal microvilli, syndecan-3 (Goutebroze et al., 2003), was not consistently found at nodes and heminodes in Trembler-J mice (supplemental Fig. 2, available at www.jneurosci.org as supplemental material). Thus, the Schwann cell processes that contact Trembler- $J$ nodes and heminodes lack typical ultrastructural and molecular specializations of the mature microvilli.

\section{Altered localization of juxtaparanodal proteins}

Given the evidence that the paranode is a barrier for ion channel diffusion (Pedraza et al., 2001; Poliak and Peles, 2003), we investigated the localization of Kv1.1 and Kv1.2, using MAG as a paranodal marker. As noted previously in other demyelinating conditions (Rasband et al., 1998; Arroyo et al., 1999, 2002), Kv1.1 and Kv1.2 were colocalized (Fig. $4 A-E$ ). The distribution of

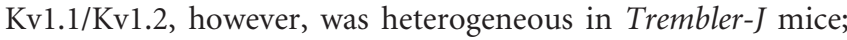
this could be related to the heterogeneity of the paranodal structure (Fig. 1). Only 35\% of the fibers had normal juxtaparanodal Kv1.2 staining, separated from the nodes by MAG-labeled paranodes (Fig. $4 A$ ), in contrast to $95 \%$ in WT nerves (Table 1). Of the remaining fibers, $35 \%$ had diffuse Kv1.2 staining along their internodes with an increased intensity at presumptive paranodes (Fig. 4 B), 15\% had Kv1.2 in both the unmyelinated gap (between heminodes) and the paranodal region (Fig. 4C), and 15\% lacked detectable Kv1.2 staining. Double staining with the Nav channels revealed that the nodes and heminodes (Fig. 4D, arrowhead) lacked Kv1.2 channels. Double labeling with Caspr (Fig. $4 E$ ) or $\mathrm{RPTP} \beta$-Fc (data not shown) demonstrated that, despite the apparent paranodal localization of $\mathrm{Kv} 1.1 / \mathrm{Kv} 1.2$, short paranodes still excluded Kv1 channels. Altogether, these results indicate that the integrity of the paranode is crucial for the juxtaparanodal sequestration of Kvl channels but not their exclusion from the nodes/heminodes.

\section{Aberrant expression of ion channels in Trembler-J nodes}

PNS nodes in Mpz-null mice contain Nav1.8, a tetrodotoxin (TTX)-resistant channel (Ulzheimer et al., 2004). In teased fibers from Trembler-J nerves (Table 1), Nav1.8 was found in $72 \%$ of nodes and heminodes (Fig. $4 H-J$ ). Unmyelinated segments between heminodes did not contain detectable Nav1.8 immunostaining. Because Nav1.8 is expressed in sensory neurons (Akopian et al., 1996; Sangameswaran et al., 1996) and even in some CNS nodes (Arroyo et al., 2002), we examined sciatic nerves as well as ventral and dorsal roots of adult WT and Trembler-J mice. We did not find Nav1.8-positive nodes in WT dorsal or ventral roots or in Trembler-J ventral roots, whereas many nodes were Nav1.8 positive in Trembler- $J$ dorsal roots (data not shown). Because all nodes are Nav1.6 positive, Nav1.8 coexists with Nav1.6 at nodes and heminodes in sensory axons of Trembler-J mice. 
Nav1.8 staining revealed similar numbers of small Nav1.8-positive neurons in lumbar DRGs of adult Trembler-J and WT mice (data not shown); there was no evidence of increased Nav1.8 expression in sensory neurons.

$\mathrm{Kv} 3.1 \mathrm{~b}$ is a voltage-dependent $\mathrm{K}^{+}$ channel mainly expressed in CNS nodes (Devaux et al., 2003). Its expression was increased in Trembler- $J$ nerves: nodal staining was more prominent (Fig. $5 A, B$ ), and a higher proportion of Trembler- $J$ nodes were Kv3.1b positive (69 vs $20 \%$ ) (Table 1). Kv3.1b was found in heminodes but not in the unmyelinated segments between them (Fig. 5B,C). Kv3.1b-positive nodes were observed in both dorsal and ventral roots (data not shown), indicating that Kv3.1b expression is not a matter of axonal type. Because contactin and tenascin-R are present in CNS but not PNS nodes (Bjartmar et al., 1994; Rios et al., 2000), both are plausible partners for addressing Kv3.1b to nodes (Devaux et al., 2003). We excluded this possibility: tenascin- $\mathrm{R}$ was not detected (data not shown), and contactin was only found at paranodes in both WT and Trembler-J nerves (Fig. 5E, F).

To corroborate these findings, we immunoblotted homogenates of adult peripheral nerve from WT and Trembler-J mice for Nav1.8 and Kv3.1. In accord with our previous failure to detect $\mathrm{Kv} 3.1$ and KCNQ2 in immunoblots of normal adult nerve (Devaux et al., 2003, 2004), neither Nav1.8 nor Kv3.1 was detected (supplemental Fig. 3, available at www.jneurosci.org as supplemental material).

\section{Electrophysiology of Trembler-J nerves}

To confirm and extend the above findings, we recorded extracellular CAPs. Compared with WT sciatic nerves, these were delayed, dispersed, and reduced 20-fold in amplitude in Trembler-J nerves (Fig. 6A-F). Conduction velocity was decreased $(9.1 \pm$ 1.9 vs $34.7 \pm 4.7 \mathrm{~m} / \mathrm{s}$ ). The decreased area under the curve of the CAPs, from $2692 \pm 1103$ to $317 \pm 101$ (arbitrary units; $p<0.001$; one tailed $t$ tests), indicates that the decreased amplitude is not the result of temporal dispersion alone; conduction failure and/or axonal loss also contribute. Altogether, these results demonstrated that the safety factor of AP propagation is decreased in Trembler-J nerves. The intensity of the stimulus required to recruit the Trembler-J CAPs was significantly higher (Fig. 6G), and there was a small but significant increase in the refractory period of the CAPs (Fig. $6 H$ ), suggesting that Nav channels might remain inactivated longer in Trembler-J mice.

To evaluate the possible functional importance of nodal Nav1.8 expression in Trembler-J nerves, we compared the effects of TTX on the CAPs recorded from WT and Trembler-J sciatic nerves. If Nav1.8 was involved in AP regeneration at nodes and/or heminodes, then CAPs should be relatively resistant to low concentrations of TTX (10-100 nM). We observed the opposite effect: TTX reduced the CAPs of Trembler-J nerves at even lower concentrations than in WT nerves (Fig. 7). These results confirmed that the safety factor of AP propagation is decreased in Trembler-J nerves and indicate that TTX-sensitive subunits such as Nav1.6 are more important for AP regeneration. These findings do not exclude the possibility that Nav1.8 channels participate in AP regeneration; for example, they might be activated consequently to TTX-sensitive channels.

\section{Discussion}

\section{Paranodal alterations in Trembler-J nerves}

Our results extend previous studies on heterozygote Trembler and Trembler-J nerves, which described morphology changes, notably the presence of segmental demyelination and remyelination, as well as Schwann cell proliferation, apoptosis, and axonal loss (Low, 1976a,b; Henry et al., 1983; Beuche and Friede, 1985; Friede, 1986; Robertson et al., 1997, 1999). These changes are not unique to Trembler and Trembler-Jbut rather are characteristic of all severe, demyelinating neuropathies, including Pmp22- and Mpz-null mice (Wrabetz et al., 2004).

\section{Altered paranodes in Trembler-J mice}

Despite ongoing segmental demyelination and remyelination, Caspr and contactin clustered at paranodes, and septate-like junctions were formed (Einheber et al., 1997; Menegoz et al., 1997; Rios et al., 2000). Paranodes were shorter than usual and often exhibited an "unrolled" appearance similar to that of im- 

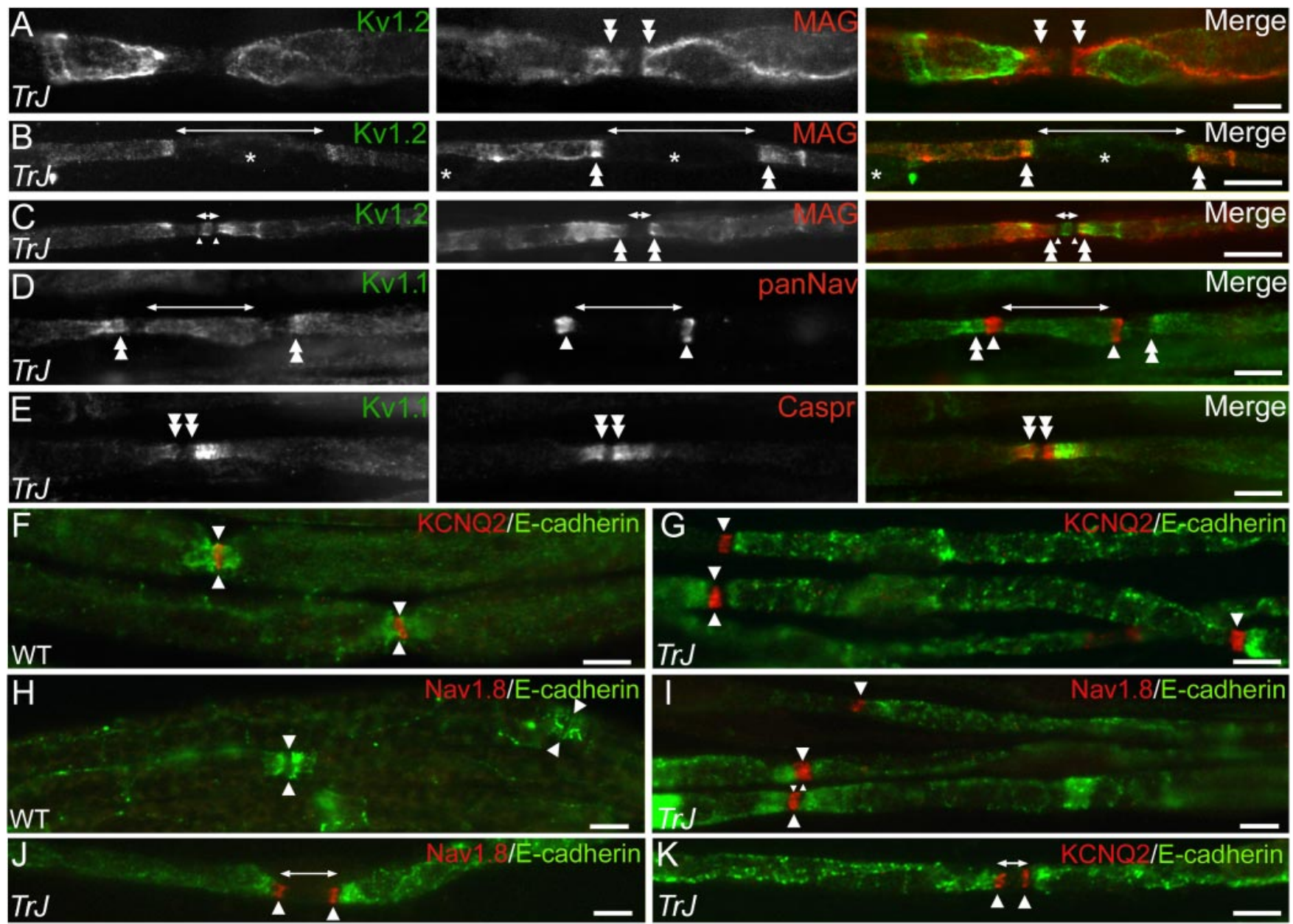

Figure 4. Kv1.1, Kv1.2, KCNQ2, and Nav1.8 channels in Trembler-J mice. These are images of unfixed teased sciatic nerve fibers from WT and Trembler-J (TrJ) mice, labeled as indicated. In many internodes, Kv1.1 and Kv1.2 staining was normally localized to the juxtaparanodal region ( $A$ ). In most fibers, however, Kv1.1 and Kv1.2 was abnormally localized in the paranodal region (double arrowheads in $B-D$ ) or in the unmyelinated segments between two heminodes (bars with arrows in $C, D$ ). Kv1.1 and Kv1.2 flanked the nodes and heminodes but did colocalize with Nav channels ( $D$ ). Even altered paranodes still segregated Kv1.1 and Kv1.2 channels ( $E$ ). KCNQ2 staining was found in both WT ( $F$ ) and Trembler-J ( $G$ ) nodes (apposed arrowheads) and Trembler-J heminodes ( $K$ ). In contrast, Nav1.8 was detected in Trembler-J nodes $(I)$ and heminodes $(J)$ but not in WT nodes $(H)$. Asterisks indicate Schwann cell nuclei. Scale bars, $10 \mu \mathrm{m}$.

mature myelinated fibers (Pedraza et al., 2001), suggesting that remyelination recapitulates development but results in thinner than normal myelin sheaths.

Despite their aberrant size, paranodes still segregated Kv1.1 and Kv1.2 from the nodes. In many cases, the separation was small and certainly improper for electrical insulation of the internodal regions; this probably contributes to the electrophysiological abnormalities in Trembler-J mice. In various mutant mice that lack septate-like junctions (with otherwise intact myelin sheaths), Kv1.1 and Kv1.2 abut nodal Nav channels, with demonstrable electrophysiological consequences (Coetzee et al., 1996; Dupree et al., 1998; Bhat et al., 2001; Boyle et al., 2001). Kv1.1 and Kv1.2 were found in unmyelinated segments (between heminodes) but did not colocalize with the Nav channels, indicating that the exclusion of Kv1.1/Kv1.2 from nodes does not require the presence of paranodes. Perhaps nodes have a diffusion barrier preventing the lateral diffusion of molecules, like axon initial segments (Winckler et al., 1999; Nakada et al., 2003).

\section{Channel subunits in Trembler-J nodes}

Ankyrin-G has been reported previously to cluster at nodes and heminodes in Trembler-J mice (Lambert et al., 1997). We herein show that not only ankyrin-G clusters at nodes and heminodes but also KCNQ2, Nav channels, and $\beta I V$-spectrin, and that none of these constituents are detectable in unmyelinated segments between heminodes. These nodes and heminodes were covered by Schwann cell processes that lack many of the distinct ultrastructural and molecular characteristics of microvilli, yet may, nevertheless, mediate nodal clustering of axonal molecules (Vabnick et al., 1996; Rasband et al., 1999; Scherer et al., 2004). Whereas trans-interactions between Schwann cell microvilli and nodal axonal membranes have been proposed to cluster Nav channels (Bennett et al., 1997; Saito et al., 2003; Salzer, 2003), the molecules that mediate these interactions have not been identified. Our findings indicate that neither EBP-50 (and by extension, ERM proteins) nor syndecan-3 are required for the proper nodal clustering of axonal proteins. This conclusion does not contradict previously published data (Scherer et al., 2001; Gatto et al., 2003; Goutebroze et al., 2003; Melendez-Vasquez et al., 2004) because ERMs, EBP-50, and syndecan-3 have only been shown to mark the glial processes that are found in conjunction with nodal clusters; there is no evidence that any of these molecules are required for nodal clustering.

Nav1.2 was not detectably expressed in Trembler-J sciatic nerves. This contrasts with the CNS, in which Nav1.2 appears to be reexpressed or retained at nodes and along the axon after 
demyelination or dysmyelination (Boiko et al., 2001, 2003; Kaplan et al., 2001; Craner et al., 2003; Rasband et al., 2003; Rios et al., 2003; Suzuki et al., 2004). Nav1.2, however, is not widely expressed by PNS and spinal cord neurons (Westenbroek et al., 1989; Waxman et al., 1999; Arroyo et al., 2002), so perhaps the phenomenon of Nav1.2 retention/reexpression is limited to the neurons expressing it. The nature of the myelinating glial cell may also influence the expression of the nodal Nav subunit, as suggested by Suzuki et al. (2004) in mice that lack sulfatide.

Both Mpz-null mice (Martini et al., 1995; Ulzheimer et al., 2004) and Trembler-J mice have increased nodal expression of Nav1.8, indicating that this may be a general alteration in demyelinating neuropathies. Because Nav1.8-positive nodes were detected in dorsal but not in ventral roots, it is likely that only sensory axons express it. Although $80 \%$ of myelinated axons in the rodent sciatic nerve are sensory (Swett et al., 1991, 1995), Nav1.8 is mainly express by nociceptive neurons, which lack myelinated axons (Akopian et al., 1996; Sangameswaran et al., 1996). These data imply that myelinated sensory afferents acquire nodal Nav1.8 expression, but they do not illuminate the cause. It is unlikely that annexin II is involved, as described for dorsal root ganglion cells (Okuse et al., 2002), because we did not detect it at nodes (data not shown). Because we did not detect widespread Nav1.8 expression in developing nerves (data not shown), it is unlikely that its increased expression in Trembler-J nerves represents a persistence/recapitulation of development, as has been argued for Nav1.2 in the CNS (see above). The nodal expression of Nav1.8 could be related to inflammatory changes that occur in demyelinating neuropathies (Maurer et al., 2002), as Nav1.8 expression increases after nerve injury (Akopian et al., 1999; Gold et al., 2003; Roza et al., 2003). This possibility seems unlikely because there were no obvious differences in the number of Nav1.8-positive neurons in the lumbar ganglia or in the intensity of immunostaining of unmyelinated axons between Trembler-J and WT mice (data not shown) (cf. Gold et al., 2003).

\section{Kv3.1b in Trembler-J nodes}

Trembler-J nodes appear to contain increased levels of Kv3.1b, which may be source of the fast nodal current, $\mathrm{K}_{\mathrm{f} 2}$ (Corrette et al., 1991). As we reported previously (Devaux et al., 2003), Kv3.1b is mainly detected at CNS nodes; a low proportion of PNS nodes are Kv3.1b positive in WT nerves and are less strikingly stained than those in Trembler-J. We excluded the possibility that contactin or tenascin-R might address Kv3.1b to nodes, because these two proteins were absent from Trembler-J nodes. Unlike Nav1.2, Kv3.1b is not expressed at early stage of myelination in the PNS (Devaux et al., 2003). Therefore, its presence cannot be explained by nodal retention, as suggested for Nav1.2 in Caspr- or Cst-null mice (Rios et al., 2003; Suzuki et al., 2004). Whether the mechanism of increased nodal Kv3.1b expression is related to the increased expression of Nav1.8 remains to be determined.
Table 1. Quantification of Kv1.2, Kv3.1b, Nav1.8, and Nav1.2 labeling

\begin{tabular}{lll}
\hline & $T r J$ & WT \\
\hline Kv1.2 & & \\
Juxtaparanodal & $35 \%$ & $95 \%$ \\
Paranodal & $35 \%$ & $3.7 \%$ \\
$\begin{array}{l}\text { Paranodal and } \\
\text { unmyelinated }\end{array}$ & & \\
gap & & \\
No staining & $15 \%$ & $0.9 \%$ \\
$n$ & $15 \%$ & $0.9 \%$ \\
Kv3.1b & 235 & 109 \\
Positive node & & \\
Negative node & $69 \%$ & $20 . \%$ \\
$n$ & $31 \%$ & $80 . \%$ \\
Nav1.8 & 333 & 148 \\
Positive node & & \\
Negative node & $72 \%$ & N.F. \\
$n$ & $28 \%$ & - \\
Nav1.2 & 541 & $>200$ \\
Positive node & & \\
$n$ & N.F. & N.F. \\
\hline
\end{tabular}

Data were collected from Trembler-J $(n=3)$ mice and their WT littermates and are represented as percentage of the total number of nodes and heminodes examined. The nodal and paranodal regions were identified using a monoclonal antibody against panNav and a monoclonal antibody against MAG or E-cadherin, respectively. N.F., None found.

Electrophysiological alterations in chronic demyelination Nerve conduction velocities (NCVs) are a traditional of classifying CMT. For autosomal dominant forms, whether the forearm motor NCVs are greater or less than $38 \mathrm{~m} / \mathrm{s}$ is a useful, but sometimes inaccurate, way of separating the neuronal/axonal forms 


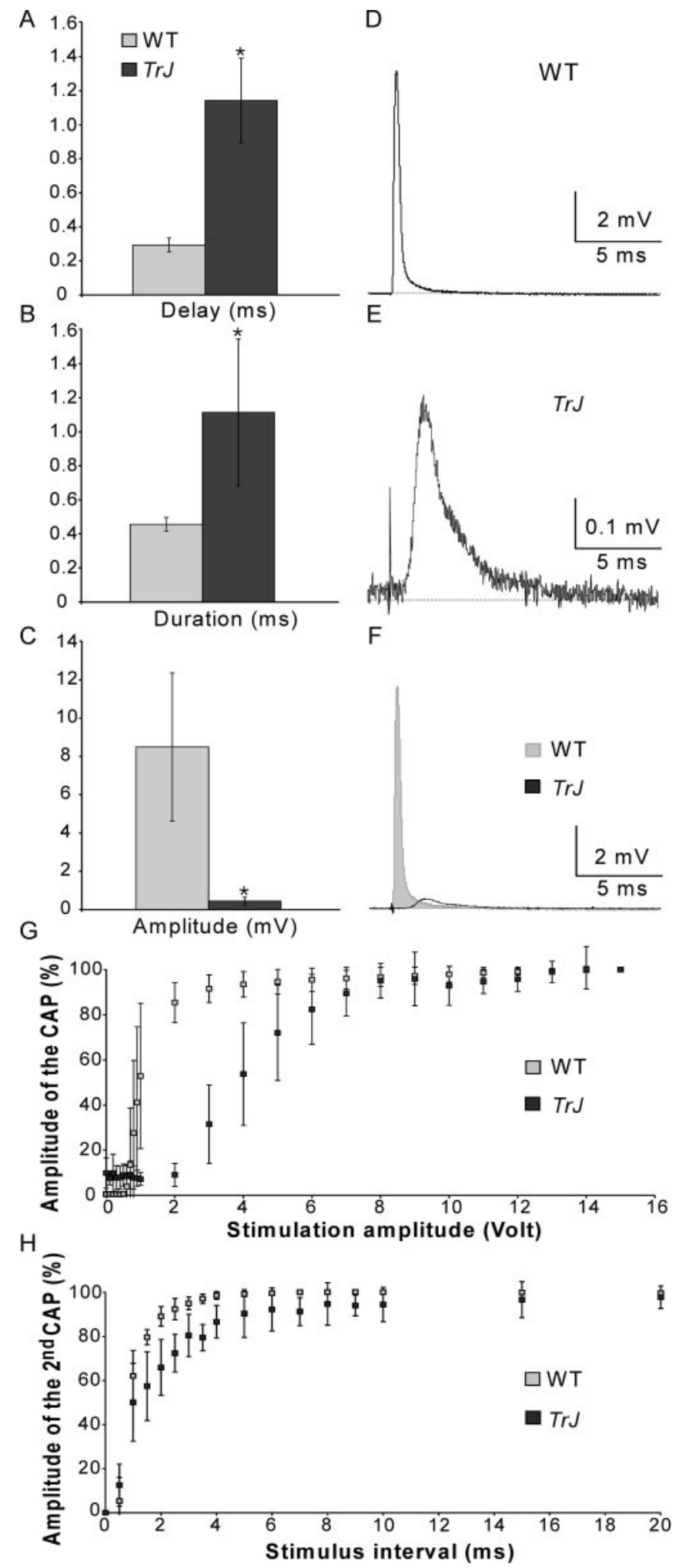

Figure 6. Electrophysiological characteristics of Trembler-J nerves. CAPs recorded from Trembler-J $(T r J)$ sciatic nerves $(n=8)$ were delayed $(A ; p<0.001)$, more dispersed $(B ; p<$ $0.001)$, and smaller $(C ; p<0.001)$ than those in WT $(n=9)$ nerves. Examples of WT and Trembler-J CAPs are shown in $D$ and $E$, respectively; both traces are superposed in $F$. Trembler-J fibers were recruited at higher stimulus intensities $(G ; p<0.05$ for stimulation intensities of $1-5 \mathrm{~V}$ ) and had longer refractory periods ( $H ; p<0.05$ for stimulus intervals between 1 and 10 $\mathrm{ms})$. One-tailed $t$ tests for two samples of equal variance were used in all of the above comparisons.

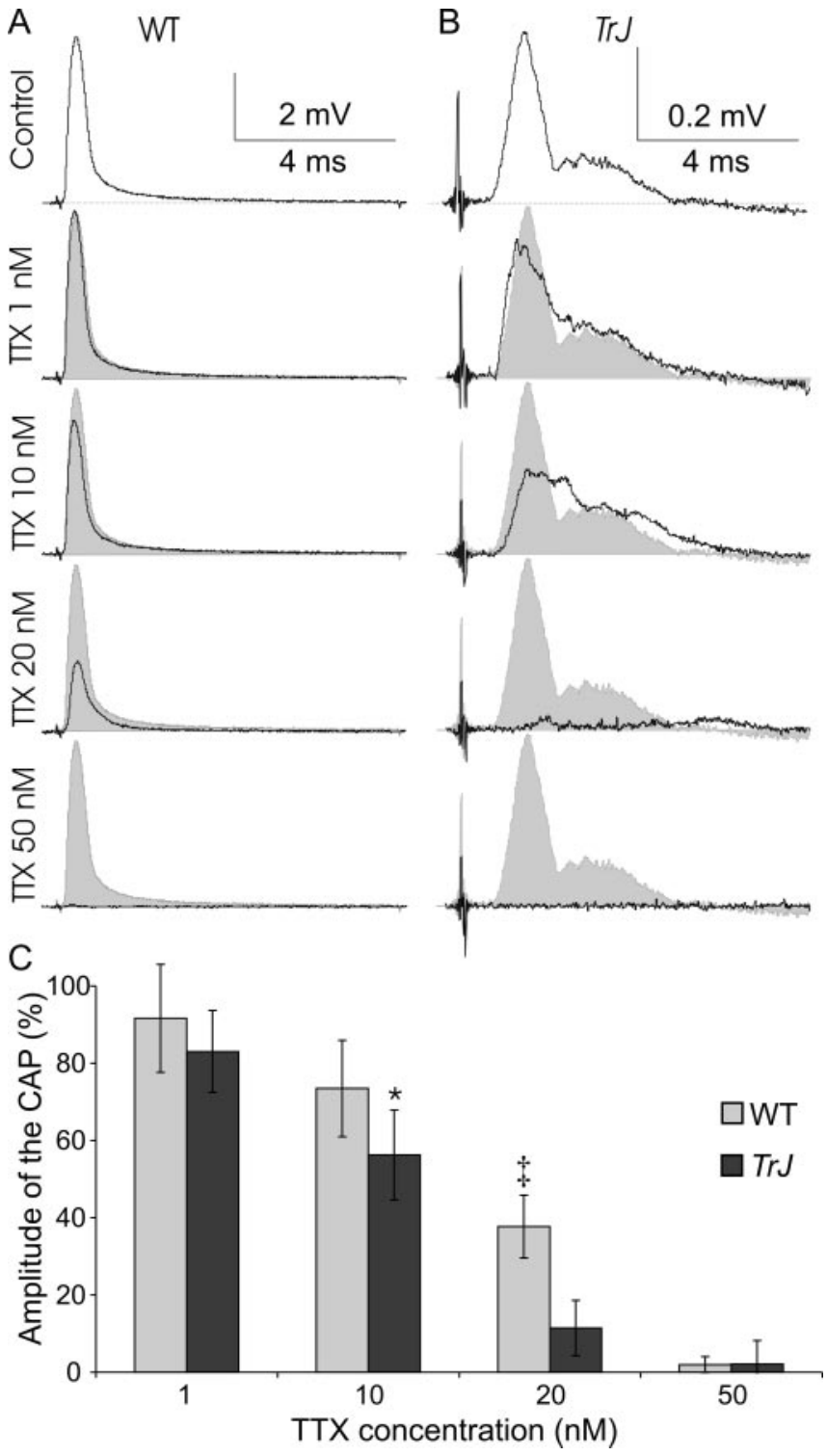

Figure 7. Trembler-J nerves are not relatively resistant to TTX. Increasing concentrations of TTX decrease the amplitude of CAPs in WT $(A ; n=5)$ and Trembler-J $(T r J)(B ; n=6)$ nerves. Examples of single nerves are shown in $A$ and $B ;($ shows the averages. At 10 and $20 \mathrm{~nm}$, TTX decreased the CAP of Trembler-J nerves more than that of WT nerves $\left({ }^{*} p<0.05,{ }^{\ddagger} p<0.001\right.$, using a one-tailed $t$ tests for two samples of equal variance). At $50 \mathrm{~nm} \mathrm{TTX,} \mathrm{(APS} \mathrm{were} \mathrm{blocked} \mathrm{in}$ both WT and Trembler-J nerves.

(CMT2) from the demyelinating forms (CMT1), respectively (Harding and Thomas, 1980; Kleopa and Scherer, 2002). NCVs are comparably affected in Trembler-J mice $(9 \mathrm{~m} / \mathrm{s})$ as in humans with the identical mutation $(9-15 \mathrm{~m} / \mathrm{s}$ ) (Valentijn et al., 1992; Hoogendijk et al., 1993). NCV are even slower $(5 \mathrm{~m} / \mathrm{s})$ in Trembler mice (Low and McLeod, 1977) and humans with the identical missense mutation (Gly150Asp) (Suter et al., 1992b; Ionasescu et al., 1997), which correlate with their more severe demyelinating neuropathy (Low, 1976a,b; Henry et al., 1983; Beuche and Friede, 1985; Friede, 1986). Humans with the other missense mutations also present severe phenotypes and severely slowed NCVs (Fabrizi et al., 1999, 2000; Simonati et al., Fabrizi et al., 2001) (for review, see Nelis et al., 1999).

In addition to slowed NCVs, Trembler (Low and McLeod, 1977) and Trembler-J (this study) mice have an abnormal refractory period and recruitment. At stimulus intensities sufficient to 
recruit nearly all fibers in WT nerves $(\sim 4 \mathrm{~V})$, only one-half were activated in Trembler-J nerves. These findings can be explained by the biophysical changes in Trembler-J nodes, notably by decreased myelin and paranodal resistance, increased nodal area, and therefore increased nodal capacitance and conductance. It is likely that the $\mathrm{K}^{+}$channels found at nodes and unmyelinated segments participate in these abnormalities by shunting down the depolarizing currents. Whether abnormalities in Nav1.6 contribute to these electrophysiological abnormalities is uncertain: Nav1.6 appears to be properly clustered at nodes and heminodes, but it is possible that the density of Nav1.6 is decreased.

Slowly inactivating Nav1.8 subunits (Akopian et al., 1996; Sangameswaran et al., 1996) might contribute to the increased refractory period of Trembler-J nerves. TTX treatment, however, failed to provide evidence for a role of Nav1.8 in AP regeneration. In addition, vinpocetine, which blocks Nav1.8 channels without any known effects on the other Nav subunits (Zhou et al., 2003), did not have much effect on Trembler-J nerves (100 $\mu \mathrm{M}$; data not shown). Thus, whether Nav1.8 functions at Trembler-J nodes remains to be proven. Even if nodal Nav1.8 subunits at nodes do not affect conduction, increasing their activity/functionality could be therapeutic, because decreasing the inactivation of the Nav channels might favor axonal conduction (Bostock et al., 1978).

\section{References}

Akopian AN, Sivilotti L, Wood JN (1996) A tetrodotoxin-resistant voltagegated sodium channel expressed by sensory neurons. Nature 379:257-262.

Akopian AN, Souslova V, England S, Okuse K, Ogata N, Ure J, Smith A, Kerr BJ, McMahon SB, Boyce S, Hill R, Stanfa LC, Dickenson AH, Wood JN (1999) The tetrodotoxin-resistant sodium channel SNS has a specialized function in pain pathways. Nat Neurosci 2:541-548.

Arroyo EJ, Xu Y-T, Zhou L, Messing A, Peles E, Chiu SY, Scherer SS (1999) Myelinating Schwann cells determine the internodal localization of Kv1.1, Kv1.2, Kv $\beta 2$, and Caspr. J Neurocytol 28:333-347.

Arroyo EJ, Xu T, Grinspan J, Lambert S, Levinson SR, Brophy PJ, Peles E, Scherer SS (2002) Genetic dysmyelination alters the molecular architecture of the nodal region. J Neurosci 22:1726-1737.

Bennett V, Lambert S, Davis JQ, Zhang X (1997) Molecular architecture of the specialized axonal membrane at the node of Ranvier. Soc Gen Physiol 52:107-120.

Berghs S, Aggujaro D, Dirkx R, Maksimova E, Stabach P, Hermel JM, Zhang JP, Philbrick W, Slepnev V, Ort T, Solimena M (2000) beta IV spectrin, a new spectrin localized at axon initial segments and nodes of Ranvier in the central and peripheral nervous system. J Cell Biol 151:985-1001.

Beuche W, Friede RL (1985) A quantitative assessment of myelin sheaths in the peripheral nerves of dystrophic, quaking, and Trembler mutants. Acta Neuropathol 60:29-36.

Bhat MA, Rios JC, Lu Y, Garcia-Fresco GP, Ching W, St Martin M, Li JJ, Einheber S, Chesler M, Rosenbluth J, Salzer JL, Bellen HJ (2001) Axonglia interactions and the domain organization of myelinated axons requires Neurexin IV/Caspr/Paranodin. Neuron 30:369-383.

Bjartmar C, Karlsson B, Hildebrand C (1994) Cellular and extracellular components at nodes of Ranvier in rat white matter. Brain Res 667:111-114.

Boiko T, Rasband MN, Levinson SR, Coldwell JH, Mandel G, Trimmer JS, Matthews G (2001) Compact myelin dictates the differential targeting of two sodium channel isoforms in the same axon. Neuron 30:91-104.

Boiko T, VanWart A, Caldwell JH, Levinson SR, Trimmer JS, Matthews G (2003) Functional specialization of the axon initial segment by isoformspecific sodium channel targeting. J Neurosci 23:2306-2313.

Bostock H, Sherratt RM, Sears TA (1978) Overcoming conduction failure in demyelinated nerve fibres by prolonged action potentials. Nature 274:385-387.

Boyle MET, Berglund EO, Murai KK, Weber L, Peles E, Ranscht B (2001) Contactin orchestrates assembly of the septate-like junctions at the paranode in myelinated peripheral nerve. Neuron 30:385-397.

Browne DL, Gancher ST, Nutt JG, Brunt ERP, Smith EA, Kramer P, Litt M
(1994) Episodic ataxia/myokymia syndrome is associated with point mutations in the human potassium channel gene, KCNA1. Nat Genet 8:136-140.

Caldwell JH, Schaller KL, Lasher RS, Peles E, Levinson SR (2000) Sodium channel $\mathrm{Na}_{\mathrm{V}} 1.6$ is localized at nodes of Ranvier, dendrites, and synapses. Proc Natl Acad Sci USA 97:5616-5620.

Coetzee T, Fujita N, Dupree J, Shi R, Blight A, Suzuki K, Suzuki K, Popko B (1996) Myelination in the absence of galactocerebroside and sulfatide: normal structure with abnormal function and regional instability. Cell 86:209-219.

Cooper EC, Harrington E, Jan YN, Jan LY (2001) M channel KCNQ2 subunits are localized to key sites for control of neuronal network oscillations and synchronization in mouse brain. J Neurosci 21:9529-9540.

Corrette B, Repp H, Dreyer F, Schwarz J (1991) Two types of fast $\mathrm{K}^{+}$channels in rat myelinated fibres and their sensitivity to dendrotoxin. Pflügers Arch 418:408-416.

Craner MJ, Lo AC, Black JA, Waxman SG (2003) Abnormal sodium channel distribution in optic nerve axons in a model of inflammatory demyelination. Brain 126:1552-1561.

Devaux J, Gola M, Jacquet G, Crest M (2002) Effects of K ${ }^{+}$channel blockers on developing rat myelinated CNS axons: identification of four types of $\mathrm{K}^{+}$channels. J Neurophysiol 87:1376-1385.

Devaux J, Alcaraz G, Grinspan J, Bennett V, Joho R, Crest M, Scherer SS (2003) Kv3.1b is a novel component of CNS nodes. J Neurosci 23:4509-4518.

Devaux JJ, Kleopa KA, Cooper EC, Scherer SS (2004) KCNQ2 is a nodal $\mathrm{K}^{+}$ channel. J Neurosci 24:1236-1244.

Djouhri L, Fang X, Okuse K, Wood JN, Berry CM, Lawson SN (2003) The TTX-resistant sodium channel $\mathrm{Na}(\mathrm{V}) 1.8$ (SNS/PN3): expression and correlation with membrane properties in rat nociceptive primary afferent neurons. J Physiol (Lond) 550:739-752.

Dupree JL, Coetzee T, Blight A, Suzuki K, Popko B (1998) Myelin galactolipids are essential for proper node of Ranvier formation in the CNS. J Neurosci 18:1642-1649.

Dyck PJ (1993) Neuronal atrophy and degeneration predominantly affecting peripheral sensory and autonomic neurons. In: Peripheral neuropathy, Ed 3 (Dyck PJ, Thomas PK, Griffin JW, Low PA, Poduslo JF, eds), pp 1065-1093. Philadelphia: Saunders.

Einheber S, Zanazzi G, Ching W, Scherer SS, Milner TA, Peles E, Salzer JL (1997) The axonal membrane protein Caspr/Neurexin IV is a component of the septate-like paranodal junctions that assemble during myelination. J Cell Biol 139:1495-1506.

Eunson LH, Rea R, Zuberi SM, Youroukos S, Panayiotopoulos CP, Liguori R, Avoni P, McWilliam RC, Stephenson JBP, Hanna MG, Kullmann DM, Spauschus A (2000) Clinical, genetic, and expression studies of mutations in the potassium channel gene KCNA1 reveal new phenotypic variability. Ann Neurol 48:647-656.

Fabrizi GM, Cavallaro T, Taioli F, Orrico D, Morbin M, Simonati A, Rizzuto N (1999) Myelin uncompaction in Charcot-Marie-Tooth neuropathy type 1A with a point mutation of peripheral myelin protein-22. Neurology 53:846-851.

Fabrizi GM, Simonati A, Taioli F, Cavallaro T, Ferrarini M, Rigatelli F, Pini A, Mostacciuolo ML, Rizzuto N (2001) PMP22 related congenital hypomyelination neuropathy. J Neurol Neurosurg Psychiatry 70:123-126.

Fannon AM, Sherman DL, Ilyina-Gragerova G, Brophy PJ, Friedrich VL, Colman DR (1995) Novel E-cadherin mediated adhesion in peripheral nerve: Schwann cell architecture is stabilized by autotypic adherens junctions. J Cell Biol 129:189-202.

Friede RL (1986) Relation between myelin sheath thickness, internode geometry, and sheath resistance. Exp Neurol 92:234-247.

Gatto CL, Walker BJ, Lambert S (2003) Local ERM activation and dynamic growth cones at Schwann cell tips implicated in efficient formation of nodes of Ranvier. J Cell Biol 162:489-498.

Gold MS, Weinreich D, Kim CS, Wang RZ, Treanor J, Porreca F, Lai J (2003) Redistribution of $\mathrm{Na}(\mathrm{V}) 1.8$ in uninjured axons enables neuropathic pain. J Neurosci 23:158-166.

Goutebroze L, Carnaud M, Denisenko N, Boutterin MC, Girault JA (2003) Syndecan-3 and syndecan- 4 are enriched in Schwann cell perinodal processes. BMC Neuroscience 4:29.

Harding AE, Thomas PK (1980) The clinical features of hereditary motor and sensory neuropathy types I and II. Brain 103:259-280.

Henry EW, Cowen JS, Sidman RL (1983) Comparison of Trembler and 
Trembler-J phenotypes: varying severity of peripheral hypomyelination. J Neuropathol Exp Neurol 42:688-706.

Hoogendijk JE, Janssen EAM, Gabreels-Festen AAWM, Hensels GW, Joosten EMG, Gabreels FJM, Zorn I, Valentijn LJ, Baas F, Ongerboer de Visser BW, Bolhuis PA (1993) Allelic heterogeneity in hereditary motor and sensory neuropathy type Ia (Charcot-Marie-Tooth disease type Ia). Neurology 43:1010-1015.

Ionasescu VV, Searby CC, Ionasescu R, Chatkupt S, Patel N, Koenigsberger R (1997) Dejerine-Sottas neuropathy in mother and son with same point mutation of PMP22 gene. Muscle Nerve 20:97-99.

Jenkins SM, Bennett V (2001) Ankyrin-G coordinates assembly of the spectrin-based membrane skeleton, voltage-gated sodium channels, and L1 CAMs at Purkinje neuron initial segments. J Cell Biol 155:739-746.

Jenkins SM, Kizhatil K, Kramarcy NR, Sen A, Sealock R, Bennett V (2001) FIGQY phosphorylation defines discrete populations of L1 cell adhesion molecules at sites of cell-cell contact and in migrating neurons. J Cell Sci 114:3823-3835.

Kaplan MR, Cho M-H, Ullian EM, Isom LL, Levinson SR, Barres BA (2001) Differential control of clustering of the sodium channels $\mathrm{Na}_{\mathrm{v}} 1.2$ and $\mathrm{Na}_{\mathrm{v}} 1.6$ at developing CNS nodes of Ranvier. Neuron 40:105-119.

Kleopa KA, Scherer SS (2002) Inherited neuropathies. Neurol Clin N Am 20:679-709.

Komada M, Soriano P (2002) beta IV-spectrin regulates sodium channel clustering through ankyrin-G at axon initial segments and nodes of Ranvier. J Cell Biol 156:337-348.

Kordeli E, Lambert S, Bennett V (1995) Ankyrin $_{\mathrm{G}}$ : a new ankyrin gene with neural-specific isoforms localized at the axonal initial segment and node of Ranvier. J Biol Chem 270:2352-2359.

Lambert S, Davis JQ, Bennett V (1997) Morphogenesis of the node of Ranvier: co-clusters of ankyrin and ankyrin-binding integral proteins define early developmental intermediates. J Neurosci 17:7025-7036.

Low PA (1976a) Hereditary hypertrophic neuropathy in the Trembler mouse. 1. Histopathological studies: light microscopy. J Neurol Sci 30:327-341.

Low PA (1976b) Hereditary hypertrophic neuropathy in the Trembler mouse. 2. Histopathological studies: electron microscopy. J Neurol Sci 30:343-368.

Low PA, McLeod JG (1977) Refractory period, conduction of trains of impulses, and effect of temperature on conduction in chronic hypertrophic neuropathy. J Neurol Neurosurg Psychiatry 40:434-447.

Lupski JR, Garcia CA (2001) Charcot-Marie-Tooth peripheral neuropathies and related disorders. In: The metabolic and molecular basis of inherited disease (Scriver CR, Beaudet AL, Sly WS, Valle D, eds), pp 5759-5788. New York: McGraw-Hill.

Martini R, Schachner M (1986) Immunoelectron microscopic localization of neural cell adhesion molecules (L1, N-CAM, and MAG) and their shared carbohydrates epitope and myelin basic protein in developing sciatic nerve. J Cell Biol 103:2434-2448.

Martini R, Zielasek J, Toyka KV, Giese KP, Schachner M (1995) Protein zero (P0)-deficient mice show myelin degeneration in peripheral nerves characteristic of inherited human neuropathies. Nat Genet 11:281-285.

Maurer M, Kobsar I, Berghoff M, Schmid CD, Carenini S, Martini R (2002) Role of immune cells in animal models for inherited neuropathies: facts and visions. J Anat 200:405-414.

Melendez-Vasquez CV, Rios JC, Zanazzi G, Lambert S, Bretscher A, Salzer JL (2001) Nodes of Ranvier form in association with ezrin-radixin-moesin (ERM)-positive Schwann cell processes. Proc Natl Acad Sci USA 98:1235-1240.

Melendez-Vasquez CV, Einheber S, Salzer JL (2004) Rho kinase regulates Schwann cell myelination and formation of associated axonal domains. J Neurosci 24:3953-3963.

Menegoz M, Gaspar P, Le Bert M, Galvez T, Burgaya F, Palfrey C, Ezan P, Arnos F, Girault J-A (1997) Paranodin, a glycoprotein of neuronal paranodal membranes. Neuron 19:319-331.

Nakada C, Ritchie K, Oba Y, Nakamura M, Hotta Y, Iino R, Kasai RS, Yamaguchi K, Fujiwara T, Kusumi A (2003) Accumulation of anchored proteins forms membrane diffusion barriers during neuronal polarization. Nat Cell Biol 5:626-632.

Nelis E, Haites N, Van Broeckhoven C (1999) Mutations in the peripheral myelin genes and associated genes in inherited peripheral neuropathies. Hum Mutat 13:11-28.

Okuse K, Malik-Hall M, Baker MD, Poon WY, Kong H, Chao MV, Wood JN
(2002) Annexin II light chain regulates sensory neuron-specific sodium channel expression. Nature 417:653-656.

Pedraza L, Huang JK, Colman DR (2001) Organizing principles of the axoglial apparatus. Neuron 30:335-344.

Peles E, Nativ M, Campbell PL, Sakurai T, Martinez R, Lev S, Clary DO, Schilling J, Barnea G, Plowman GD, Grumet M, Schlessinger J (1995) The carbonic anhydrase domain of receptor tyrosine phosphatase $\beta$ is a functional ligand for the axonal cell recognition molecule contactin. Cell 82:251-260.

Peles E, Nativ M, Lustig M, Grumet M, Martinez R, Plowman GD, Schlessinger J (1997) Identification of a novel contactin-associated transmembrane receptor with multiple domains implicated in protein-protein interactions. EMBO J 16:978-988.

Poliak S, Peles E (2003) The local differentiation of myelinated axons at nodes of Ranvier. Nat Rev Neurosci 4:968-980.

Rasband MN, Trimmer JS (2001) Subunit composition and novel localization of $\mathrm{K}^{+}$channels in spinal cord. J Comp Neurol 429:166-176.

Rasband M, Trimmer JS, Schwarz TL, Levinson SR, Ellisman MH, Schachner M, Shrager P (1998) Potassium channel distribution, clustering, and function in remyelinating rat axons. J Neurosci 18:36-47.

Rasband MN, Peles E, Trimmer JS, Levinson SR, Lux SE, Shrager P (1999) Dependence of nodal sodium channel clustering on paranodal axoglial contact in the developing CNS. J Neurosci 19:7516-7528.

Rasband MN, Kagawa T, Park EW, Ikenaka K, Trimmer JS (2003) Dysregulation of axonal sodium channel isoforms after adult-onset chronic demyelination. J Neurosci Res 73:465-470.

Rios JC, Melandez-Vasquez CV, Einheber S, Lustig M, Grumet M, Hemperly J, Peles E, Salzer JL (2000) Contactin-associated protein (Caspr) and contactin form a complex that is targeted to the paranodal junctions during myelination. J Neurosci 20:8354-8364.

Rios JC, Rubin M, Martin MS, Downey RT, Einheber S, Rosenbluth J, Levinson SR, Bhat M, Salzer JL (2003) Paranodal interactions regulate expression of sodium channel subtypes and provide a diffusion barrier for the node of Ranvier. J Neurosci 23:7001-7011.

Robertson AM, King RHM, Muddle JR, Thomas PK (1997) Abnormal Schwann cell/axon interactions in the Trembler-J mouse. J Anat 190:423-432.

Robertson AM, Huxley C, King RH, Thomas PK (1999) Development of early postnatal peripheral nerve abnormalities in Trembler-J and PMP22 transgenic mice. J Anat 195:331-339.

Roza C, Laird JMA, Souslova V, Wood JN, Cervero F (2003) The tetrodotoxin-resistant $\mathrm{Na}^{+}$channel Nav1.8 is essential for the expression of spontaneous activity in damaged sensory axons of mice. J Physiol (Lond) 550:921-926.

Saito F, Moore SA, Barresi R, Henry MD, Messing A, Ross-Barta SE, Cohn RD, Williamson RA, Sluka KA, Sherman DL, Brophy PJ, Schmelzer JD, Low PA, Wrabetz L, Feltri ML, Campbell KP (2003) Unique role of dystroglycan in peripheral nerve myelination, nodal structure, and sodium channel stabilization. Neuron 38:747-758.

Salzer JL (2003) Polarized domains of myelinated axons. Neuron 40:297-318.

Sancho S, Young P, Suter U (2001) Regulation of Schwann cell proliferation and apoptosis in PMP22-deficient mice and mouse models of CharcotMarie-Tooth disease type 1A. Brain 124:2177-2187.

Sangameswaran L, Delgado SG, Fish LM, Koch BD, Jakeman LB, Stewart GR, Sze P, Hunter JC, Eglen RM, Herman RC (1996) Structure and function of a novel voltage-gated, tetrodotoxin-resistant sodium channel specific to sensory neurons. J Biol Chem 271:5953-5956.

Scherer SS, Xu T, Crino P, Arroyo EJ, Gutmann DH (2001) Ezrin, radixin, and moesin are components of Schwann cell microvilli. J Neurosci Res 65:150-164.

Scherer SS, Arroyo EJ, Peles E (2004) Functional organization of the nodes of Ranvier. In: Myelin biology and disorders (Lazzarini RA, Griffin JW, Lassman H, Nave KA, Miller RH, Trapp BD, eds), pp 89-116. Oxford: Elsevier.

Schwarz JR, Eikhof G (1987) Na currents and action potentials in rat myelinated nerve fibres at 20 and 37 degrees C. Pflügers Arch 409:569-577.

Schwarz JR, Reid G, Bostock H (1995) Action potentials and membrane currents in the human node of Ranvier. Pflügers Arch 430:283-292.

Simonati A, Fabrizi GM, Pasquinelli A, Taioli F, Cavallaro T, Morbin M, Marcon G, Papini M, Rizzuto N (1999) Congenital hypomyelination 
neuropathy with Ser72Leu substitution in PMP22. Neuromuscul Disord 9:257-261.

Stys PK, Ransom BR, Waxman SG (1991) Compound action potential of nerve recorded by suction electrode: a theoretical and experimental analysis. Brain Res 546:18-32.

Suter U, Scherer SS (2003) Disease mechanisms in inherited neuropathies. Nat Rev Neurosci 4:714-726.

Suter U, Moskow JJ, Welcher AA, Snipes GJ, Kosaras B, Sidman RL, Buchberg AM, Shooter EM (1992a) A leucine-to-proline mutation in the putative 1st transmembrane domain of the $22-\mathrm{kDa}$ peripheral myelin protein in the Trembler-J mouse. Proc Natl Acad Sci USA 89:4382-4386.

Suter U, Welcher AA, Ozcelik T, Snipes GJ, Kosaras B, Francke U, BillingsGagliardi S, Sidman RL, Shooter EM (1992b) Trembler mouse carries a point mutation in a myelin gene. Nature 356:241-244.

Suzuki A, Hoshi T, Ishibashi T, Hayashi A, Yamaguchi Y, Baba H (2004) Paranodal axoglial junction is required for the maintenance of the Nav1.6-type sodium channel in the node of Ranvier in the optic nerves but not in peripheral nerve fibers in the sulfatide-deficient mice. Glia 46:274-283.

Swett JE, Torigoe T, Elie VR, Bourassa CM, Miller PG (1991) Sensory neurons of the rat sciatic nerve. Exp Neurol 114:82-103.

Swett JE, Hong CZ, Miller PG (1995) Most dorsal root ganglion neurons of the adult rat survive nerve crush injury. Somatosens Motor Res 12:177-189.

Ulzheimer JC, Peles E, Levinson SR, Martini R (2004) Altered expression of ion channel isoforms at the node of Ranvier in P0-deficient myelin mutants. Mol Cell Neurosci 25:83-94.
Vabnick I, Novakovic SD, Levinson SR, Schachner M, Shrager P (1996) The clustering of axonal sodium channels during development of the peripheral nervous system. J Neurosci 16:4914-4922.

Valentijn LJ, Baas F, Wolterman RA, Hoogendijk JE, van den Bosch NHA, Zorn I, Gabreels-Festen AWM, de Visser M, Bolhuis PA (1992) Identical point mutations of PMP-22 in Trembler-J mouse and Charcot-MarieTooth disease Type-1A. Nat Genet 2:288-291.

Waxman SG, Dib-Hajj S, Cummins TR, Black JA (1999) Sodium channels and pain. Proc Natl Acad Sci USA 96:7635-7639.

Westenbroek RE, Merrick DK, Catterall WA (1989) Differential subcellular localization of the RI and RII $\mathrm{Na}^{+}$channel subtypes in central neurons. Neuron 3:695-704.

Winckler B, Forscher P, Mellman I (1999) A diffusion barrier maintains distribution of membrane proteins in polarized neurons. Nature 397:698-701.

Wrabetz L, Feltri ML, Hanemann CO, Muller HW (2001) The molecular genetics of hereditary demyelinating neuropathies. In: Glial cell development, Ed 2 (Jessen KR, Richardson WD, eds), pp 331-354. Oxford: Oxford UP.

Wrabetz L, Feltri ML, Kleopa K, Scherer SS (2004) Inherited neuropathies: clinical, genetic, and biological features. In: Myelin biology and disorders (Lazzarini RA, Griffin JW, Lassman H, Nave KA, Miller RH, Trapp BD, eds), pp 905-951. Oxford: Elsevier.

Zhou XP, Dong XW, Crona J, Maguire M, Priestley T (2003) Vinpocetine is a potent blocker of rat $\mathrm{Na}(\mathrm{V}) 1.8$ tetrodotoxin-resistant sodium channels J Pharmacol Exp Ther 306:498-504. 